\title{
Medieval violence, the making of law and the historical present
}

\author{
Philippa Byrne
}

Abstract: This article considers how 12th- and 13th-century law codes constructed their relationship to the justice of the past. These codes did not copy past laws unthinkingly, but evaluated them, engaging in a discussion about the appropriate measure of punishment and violence. Medieval legal writing (from Frederick II's Constitutions of Melfi to Andrew Horne's Mirror of Justices, across both Roman law and canon law compilations) recognised the duty of the present to weigh up the utility of old laws. Contrary to common historiographical assumptions, medieval jurists had a subtle sense of the history and development of law, going as far as to suggest that history could be understood as defined by distinct periods of punishment; different levels of violence were appropriate to different eras. The article concludes by using Walter Benjamin's Zur Kritik der Gewalt to evaluate how critiques of past legal violence could be used by medieval rulers as a means of demonstrating the righteousness of their own regime.

Keywords: Justice, Roman law, canon law, Frederick II, Constitutions of Melfi, Andrew Horne, the Mirror of Justices, Walter Benjamin.

Note on the author: Philippa Byrne is a Departmental Lecturer in Medieval History at the University of Oxford. She works on the intellectual history of the high middle ages, with particular research interests in theological and legal traditions, the 12thcentury renaissance, and the transmission of Latin, Greek, and Arabic texts between northern Europe and the Mediterranean world. She recently published her first monograph, Justice and Mercy: Moral Theology and the Exercise of Law in Twelfth-century England with Manchester University Press, which examines the moral world of medieval judges.

philippa.byrne@history.ox.ac.uk 


\section{INTRODUCTION}

The punishment for the crime of rape is now hanging... and until the time of King Edward II this was punished by tearing out of eyes and loss of testicles, because of the appetite which entered through the eyes and the heat of fornication which came into the reins of the lechers. ${ }^{1}$

It is an abuse that justices and their officers who slay folk by false judgments are not destroyed like other homicides. And King Alfred in one year had forty four judges

hanged as homicides for their false judgments. He hanged Watling, for that he had judged Sidulf to death for receiving Erdulf his son, who was afterwards acquitted of the principle crime. He hanged Signer who had judged Ulf to death after a sufficient acquittal. He hanged Eadwine ... ${ }^{2}$

These passages, respectively recording how the penalties of English common law had been modified over time, and how the officers administering those penalties had been kept on the straight and narrow, are just two of the 'historical' examples which litter The Mirror of Justices (Miroir des Justices), a work probably composed somewhere between 1285 and 1289. The Mirror, a text which sets down a moral vision of good legal order and how that order should be enforced, is the product of a particular late13th-century English concern for abuses of the law - and a cry for their proper investigation and immediate extirpation. ${ }^{3}$ The treatise was copied and preserved for posterity by Andrew Horne, an early-14th-century London archivist, whose interest in the Mirror reflected his wider curiosity about the historical formation of the common law. The Mirror is a treatise which describes the character of English law as moral, biblical, and retributive from its foundation. Nowhere is this more strongly expressed than in the lengthy capitulum which describes how Alfred the Great had dealt, unhesitatingly and unforgivingly, with his own corrupt judges; hanging forty four of them, from a certain Athelstone to a certain Wolfston. As recent scholarship on the Mirror has noted, the value of the text for medieval historians lies not in using it to establish the reality of Alfredian justice, but in what it reveals about late13th-century perceptions about the common law. Where English rulers had once been ferocious defenders of justice, common law had since decayed into corruption. In that sense, the Mirror is not a legal but a 'para-legal' text, part of a literature which

\footnotetext{
${ }^{1}$ Whittaker $(1896$ : iv.16, 140) (though the author seems in fact to be referring to a statute of Edward I).

${ }^{2}$ Whittaker (1896: v.108, 166).

${ }^{3}$ Jahner (2014: 226); for Andrew Horne's scholarly interests, see the discussion in Sabapathy (2014: especially $1-5)$.
} 
commentated on the state of law and the state of the nation. ${ }^{4}$ It was not itself law, nor did it have any official status in the interpretation of the common law; though it could, of course, influence how that law was perceived. The efficient legal practice of the past, and the chastisement and punishment of offenders by past rulers, shamed the present and present rulers.

In a culture which set considerable store by the value of exempla as a tool of teaching, instruction and sermonising, it would have been much less compelling for the author of the treatise to simply record (or invent) a set of Alfredian legal provisions against abuses. Far more memorable and more arresting was to describe the exemplary action of punishment which accompanied Alfred's laws, as played out against forty-four different offenders. Indeed, the persuasive logic of this is not entirely lost on modern readers of the Mirror. We ourselves inhabit a world filled with narratives about how things were done better in the past - whether recent or long-distant - an idealised time when those in power were more decent, upright, or just than current holders of high office. ${ }^{5}$

The rest of this paper considers how our assumptions about medieval law and medieval punishment might change when we read both of the quotations from The Mirror of Justices which begin this paper together. The import of the Mirror's discussion of Alfred's punishment for corrupt judges seems obvious - it is an insistent moral demand for the checking of wicked officials. But why the Mirror should note the changes supposedly made to the punishment for rape during the time of Edward II (r.1307-27) seem altogether less apparent. That passage is not charged with righteous indignation: it reads as a purely historical observation, an interesting digression about how legal penalties have altered over time. This paper argues that historians and lawyers ought to pay closer attention to how medieval legal texts (and particularly law codes) described past punishments and disapplied legal penalties. There is a deliberateness to these discussions in legal texts, and a political and rhetorical purpose to a discussion of how punishment has changed over time. In considering the insertion of 'historical' narrative into legal texts, one not only develops a better sense of what law 'was' in the Middle Ages, but one can also open up a discussion about the relationship between lawful violence, and the structure of law.

One might begin with the obvious, a statement of fact about contemporary law: we do not expect to find disapplied laws within modern law codes. When a change

\footnotetext{
${ }^{4}$ This also accounts for the reception of The Mirror by Maitland and early-20th-century legal historians, who found the text insufficiently legal and excessively polemical to fall properly within the bounds of legal history. These categories have since been challenged, and modern scholarship recognises the interplay of law, moralism, satire, and polemic, and the fact that a text may be 'legal' though not composed by a lawmaker or a member of the legal profession. See Seipp (1999).
}

${ }^{5}$ Cf. Murphy (2009). 
today is made to the codified criminal law of England and Wales, new amendments are inserted and disapplied clauses are struck out. ${ }^{6}$ This is one reason why one must determine whether one is consulting legislation as it was originally enacted, or as is currently in force. When it comes to modern common law, what is past is not prologue, but extraneous material, irrelevant to practice. There is very little - if any-sense of historical development provided in the text of legislation. There are few temporal markers evident in the main body of the text, beyond the date of enactment contained in the title. We are not accustomed to imagining law on the basis of a series of historical relationships: a provision either is current or it is not.

The same was not true for medieval law codes. In those codes, we can see the validity of a particular act of punishment — of lawful, officially-sanctioned violenceagainst an offender discussed according to the historical status of the punishment. In many cases, what defined medieval law — what gave it its legitimacy, what provided for its 'lawful' status - was the demonstration that it interacted with, and was connected to, past acts of lawful violence by legitimate rulers. In short: when it came to the violent punishment of offenders, medieval law was engaged in a dialogue with the legal past. The study of this feature reveals something about both the categories of 'violence' and of 'law'.

One appealingly simple explanation for this aspect of medieval law is to connect it to a medieval mindset - a mentalité - peculiarly concerned with finding, locating, and borrowing sources of past authority. The argument runs that in a medieval 'state' without real coercive power, the invocation of past law was not merely a useful but an essential tool. Past authority could provide an essential bulwark, real legitimacy. That it most obvious in the medieval admiration for all things Roman - particularly Roman law and the Corpus Juris Civilis. The imperial hauteur of Roman lawgivers was an attractive model for medieval rulers, even before the full 'recovery' of the texts of Roman law in northern Italy in the late 11th century made the detail of Roman law fully available for imitation in royal codes. The past meant Roman authority; but it also meant invoking the authority of past 'good kings' who had punished the wicked effectively and virtuously. Naturally, the authors of medieval law-codes wished to identify themselves with rulers who had justly punished offenders through just laws.

\footnotetext{
${ }^{6}$ One might take the example of the Offences Against the Person Act (1861): ss.1-3 of the legislation as originally enacted specified death as the penalty for murder and stipulated how that sentence was to be carried out. With the abolition of the death penalty in England and Wales in 1965, the text of these sections has been removed from the current act, with only a footnote specifying the title of the later acts which removed these provisions. Without a knowledge of the relevant part(s) of the repealing act, one would not know what had formerly been stipulated in these sections. The same point could be made for the US code, and the comparable section on homicide (18 US Ch. 51), which confines its 'historical' material in notes and references to amendments.
} 
In that sense - and in a way identified by Patrick Wormald - law was as much a statement of power as it was a code to be applied; it had ideological aspirations, and that obliged it to develop a 'historical' dimension. ${ }^{7}$

One might think, for example, of the Leges Henrici Primi, an early-12th-century legal compilation from England. ${ }^{8}$ The Leges claims the authority of past precedent even when simply describing the ordering of the common law courts themselves: 'according as it was established by ancient ordinance, it has lately, through the king's beneficent command, been confirmed by faithful restatement (sicut antiqua fuerat institutione formatum ... nuper est recordatione firmatum) ${ }^{9} .{ }^{9}$ Similarly, even royal displeasure at laws being broken was expressed by endorsing and reissuing previous statements by past kings: 'it is written in the laws of King Edmund: I myself and all of us are greatly displeased by the unlawful and manifold disputes which exist between us'. ${ }^{10}$ But there is more to this than simply invocation of authority, a point which becomes evident when we turn our attention to how medieval lawmakers speak of the use of punishment in 'old' laws. Many (though not all) of these invocations of previous legal enactments are particularly focused on how the lawful punishment of offenders by violent means has changed over time. What mattered was not simply invoking past authority, but explaining and accounting for those changes - to give a sense of where the then law-giver stood in relation to a historical set of violent punishments.

The following analysis is deliberately focused on law codes promulgated or codified between the period c. 1100 and c.1250 - that is to say, codes from the period typically characterised as the beginning of 'systematic' law in Europe. ${ }^{11}$ While much has been said about the ideological claims of early medieval law, the same analysis has not been brought to law codes produced after 1100 - that is, after the beginnings of the schools of civil and canon law, the development of a legal profession, and a century-long process of legal systematisation and consistent codification. The 'systematic' law which emerged from schools at Bologna, Naples, Cologne, and the courts at Westminster in this period is typically characterised as being concise in form, precise in its stipulations, and hence 'modern'. This is a world in which past legal apparatus no longer mattered; laws contain little by way of preamble and include only such material as mattered for their application. ${ }^{12}$ Following such a narrative, the invocation of the legal past and past lawful violence done by rulers belonged to an earlier period in the

\footnotetext{
${ }^{7}$ Wormald (1999), see also Lambert (2017).

${ }^{8}$ Downer (1972); for the circumstances of its creation, see Karn, (2010).

${ }^{9}$ Leges Henrici Primi, 7.1.

${ }^{10}$ Leges Henrici Primi, 88.12.

${ }^{11}$ For one narrative of this process, see Berman (1983).

${ }^{12}$ For one example of this view, see Van Caengem (1991: 40), characterising the brevity of later-12thcentury legal enactments which no longer felt the need to satisfy legal 'niceties'.
} 
evolution of law, or was confined to the 'moral literature' of a kind typified by The Mirror of Justices; slightly rambling and lacking in precision.

Yet attention to past law, and past punishments in particular, remained a feature of law-making and law-giving in the age of systematic law. In fact, discussion of how law had changed, and how its punishments had been both increased and softened over time was an important feature-both structurally and rhetorically. Charting a history of violent punishment allowed for a dialogue which reinforced the lawfulness of the current lawgiver's enactments. In this sense it was absolutely necessary to remember past violence, and how righteous and lawful it had been. What is more, such an account allows us to reconsider a charge often levelled at medieval thought: namely that it had no real concern from chronology, no real ability to make the distinction between past and present; or where those concepts could be folded into one another. ${ }^{13}$ This is partly accurate - certainly the relationship between past and present represented a continuum without the same sharp discrepancies between 'history' and 'modernity' as we might understand them today. However, when we look to what medieval law codes say about the use of law and violence by previous rulers, we can discern a sharper distinction between past and present being asserted. Medieval law did not have a category of modernity, but it did have an understanding of how different eras might demand different approaches to the use of violence.

The two case studies which this paper uses to explore this relationship are the codification of a set of legal constitutions in 1231 by Frederick II, Holy Roman Emperor and ruler of the King of Sicily - a codification which lent heavily on the enactments of previous Sicilian rulers and the models of Roman law; and the struggles of 12th-century canonists seeking to define how exactly the punitive aspects of canon law should be applied, and old canons navigated. In both those legal contexts, lawmakers were obliged to consider when, where, and why law permitted violence as a tool of punishment, and how the exercise of violence might 'make' law.

\section{FREDERICK II AND THE CONSTITUTIONS OF MELFI}

Frederick II (1194-1250), Holy Roman Emperor and ruler of the Kingdom of Sicily, was reckoned by some apocalyptic exegetes as the Antichrist; by the papacy as a difficult, ungodly, ruler, ${ }^{14}$ and famously given the epithet stupor mundi ('wonder of the world', although a better way of capturing Frederick's notoriety during his lifetime

${ }^{13}$ For a careful discussion of this concept, see Spiegel (2016).

${ }^{14}$ McGinn (1978). 
might be to translate that title as 'world shaker'). Frederick engaged in a concerted attempt to use the techniques of legal codification and systematisation to enhance his authority-developing his efforts more deliberately and forcefully than many of his contemporaries.

In 1230, Frederick established a commission to furnish a code of laws for his Sicilian kingdom, a body which included Jacob, Archbishop of Capua, and Peter de Vinea, Frederick's trusted servant and judex magna curiae. ${ }^{15}$ The finished product, issued only a year later, came to be known as the the Constitutions of Melfi. ${ }^{16}$ The Constitutions themselves developed the attitude to law and royal authority which Frederick had set out in 1220, in his Assizes of Capua, more limited in scope. Other rulers of this period-Henry II and Alfonso X, for example - issued law, and made great claims about their legislative authority and competence. But what Frederick provides us with is a clear articulation of the comprehensive claims of these laws ${ }^{17}$. Underlining their status still further, the Constitutions were subsequently read and glossed at Naples, the university founded by Frederick in $1224 .{ }^{18}$ In the proemium to his new legal code, Frederick (or Frederick's imperial 'voice' as lawgiver) begins by equating the comprehensiveness of his code with the history of the kingdom. Frederick's initial assertion of law-giving power was tied up in an attempt to reassert rights which his predecessors had held. In Sicily, this meant invoking the memory of the previous Norman kings of Sicily (from whom Frederick claimed descent through his mother, Constance). This means the memory and legislative decisions of the 12th-century Norman kings of Sicily-Roger II, William I, and William II-are interwoven with Frederick's own laws.

The proemium of the Constitutions thus provides an account of where Frederick's law stands in a historical scheme:

We therefore desire that only the present laws under our name should be in force in the Kingdom of Sicily, and we order that those constitutions should be observed in the future, after the laws and customs contradicting these our constitutions have been annulled in this kingdom. We have commanded that all preceding laws of the kings of

\footnotetext{
${ }^{15}$ For the compilation process, see Pennington (1989). For the intellectual milieu of some of its creators, see Herde (1994).

${ }^{16}$ Constitutiones Regni Siciliae, edited by H. Dilcher (Glashütten, D. Auvermann, 1973); this is a reprint of the 1475 edition published in Naples. Unless otherwise specified, translations of the Constitutiones are those of James Powell, as found in The Liber Augustalis or Constitutions of Melfi (Syracuse, Syracuse University Press, 1971).

${ }^{17}$ For the significance of these comprehensive claims in practice in comparison with earlier legislative activities, see Jamison (1929).

${ }^{18}$ Oldfield (2009).
} 
Sicily and those of ours that we ordered to be preserved should be transferred (esse transfusas) into this collection so that ... some force and authority may obtain both inside and outside the law courts. ${ }^{19}$

Before the Constitutions engage with the specifics of its legal enactments, the complexities behind Frederick's law-making claims have been made evident. The Emperor asserts that he is wiping the slate clean - establishing a new legal order which begins from a comprehensive stance - but also that he is deliberately preserving the past by selecting those good laws which ought to continue and be transferred into the present. Indeed, this is marked in the Constitutions, where each law is preceded by the name of the king who introduced that particular provision. The majority of laws are given under Frederick's name, but the occasional annotations 'Rex Roge.' and 'Rex Guil.' stand as markers in the text; though, as is made clear, their presence in the text is only through Frederick's assent and approval. The laws of the Norman rulers of Sicily are superseded by Frederick's laws at the same time as their legislative efforts and intentions are acclaimed and integrated into the collection.

Likewise, while the laws of 12th-century Norman Sicily provided the immediate legal background for the Constitutions, Frederick is evidently in dialogue with another kind of past - the Roman, legal authority embodied by the Corpus Juris Civilis. This in itself can be no surprise: Frederick had spent the years 1212-20 pursuing his claim to the imperial title of Holy Roman Emperor. His desire to mobilise classical Roman authority is evident not merely in his legal claims, but in his commissioning of architectural works which excavate, redevelop, and restructure Roman construction material, and set them within Frederick's own iconographical schemes. ${ }^{20}$ Nor was Frederick the only medieval ruler to see the power of Roman legal precedent: the best known example of this practice is probably medieval reuse and adaptation of Roman provisions against heretics. ${ }^{21}$ Just as Justinian's Codex had dedicated its first book and title to the treatment of heretics, so did the first title of the first book of Frederick's Constitutions. ${ }^{22}$ Not only do the Constitutions follow Justinian by beginning with the appropriate punishments for heresy, but the text itself deliberately invokes the idea of continuity with classical antiquity. Heresy is an ancient problem, and Frederick's method for dealing with it in his kingdom follows that of his imperial forebears. As a crime it 'should be numbered among the public crimes as it was promulgated in the ancient laws (veteribus legibus), whenever there are those judged by their name to be sectaries'. ${ }^{23}$

\footnotetext{
${ }^{19}$ Powell (1971: 5).

${ }^{20}$ See Meredith (1994).

${ }^{21}$ Diehl (1996: especially 53-5).

${ }^{22}$ Kruger \& Mommsen (1893-95; see title 1 of the Codex, especially 1.5).

${ }^{23}$ Constitutiones, 1.1 (Powell 1971: 8).
} 
This restatement of the Roman law idea that heresy is a public crime-a crime verging on treason-is much less interesting than the dialogue opened up with the classical past elsewhere in the text. Frederick does much more than endorse the legislative decisions of his imperial predecessors; he goes beyond them, modifying their decisions. Scattered throughout the text is Frederick's invocation of his own 'imperial clemency' (imperiali mansuetudinis) to challenge and improve past imperial rulings: 'by an interpretation of our imperial clemency, we moderate the harshness of the ancient laws', he says in relation to a law which presumed anyone who wore a sword and drew it had the intention of killing. ${ }^{24}$

It would be a mistake, however, to assume Frederick consistently intervened to soften the punitive principles laid down by classical emperors. Indeed, taking the Constitutions as a whole, there is no real consistency in his attitude to the level of punitive violence sanctioned by the law. Frederick sometimes moderates imperial penalties, sometimes increases them, and he sometimes merely endorses them. $\mathrm{He}$ asserts the 'justness' of certain capital sentences set down by Roman emperors; ${ }^{25}$ he also positions himself as an upholder of the traditions of 'imperial mercy' (clementie imperialis vestigiis) established in the classical Roman past. ${ }^{26}$ Sometimes Frederick's own imperial clemency works in harmony with that of Roman emperors; on other occasions it serves to challenge their legal decisions about appropriate and proper punishment.

Thus, for every example of Frederick moderating with 'imperial clemency' one can also find an example of increased punishment, which the emperor (or his compilers) frame the text so as to draw particular attention to. Book II, for example, opens with an explanation that 'great utility and evident necessity combine with the increasing wickedness of crimes to persuade us that we should, to the best of our ability, correct that provision of the procedure for accusation established in the early laws (priscis legibus) .... ${ }^{27}$ This, of course, is not a matter of punishment or of licensing violence on the part of royal judges per se. There are further instances where Frederick positions himself as a much more severe judge than his Roman predecessors: 'we pursue the hateful folly of accusers much more than did the ancient laws insofar as we find that it is more common in our state'.$^{28}$

\footnotetext{
${ }^{24}$ Constitutiones, 1.12 (Powell: 1971: 16).

${ }^{25}$ Constitutiones, 1.22 (Powell 1971: 24): "we order that the capital punishment which the statutes of the divine Augustuses sanctioned against those who rape virgins, widows, wives or even engaged girls and their accomplices and supporters should be observed inviolably'; cf. 1.99: 'adhering to the rules of ancient law (antiquis iuris regulus inherentes), we decree ...' (Powell 1971: 59).

${ }^{26}$ Constitutiones, 2.4 (Powell 1971: 69).

${ }^{27}$ Constitutiones, 2.1 (Powell 1971: 65).

${ }^{28}$ Constitutiones, 2.12 (Powell 1971: 76).
} 
In fact, one might argue that, by asserting his right (and responsibility) to amend the laws of his predecessors, Frederick was following Roman precedent and the provisions of the Corpus Juris Civilis itself. Justinian's own first preface to the Codex makes the assertion that former emperors had recognised that many things about the law required correction, but none of them had ever managed to implement these changes. ${ }^{29}$ Making 'better' law was something all emperors had aimed at, but few had achieved. A still more developed discussion of this is found in the first book of the Codex, in which Justinian explains how his creation of the new code relates to the work of the ancient jurists and previous emperors. Justinian's Codex asserts that it begins from the constitutions left to him by his sacred predecessors, but acts to improve them through a process of correction and clarification-removing 'all pointless repetitions and unjust inconsistencies' (omni supervacua similitudine et iniquissima discordia); for only by doing so can law protect morality. ${ }^{30}$ In that sense, by invoking his own authority to rewrite legal punishments, and the difference between the society which Justinian had ruled and his own, Frederick was further 'romanising' his code.

It was not, however, only ancient laws which were in need of modification and which are presented as in need of 13th-century reassessment. Frederick is in dialogue as much with Roger II, Sicily's first Norman king, as he is with Justinian. Frederick, for example, affirms a law of Roger II by repeating, issuing, and endorsing it. This is an enactment in which Roger II himself had posed as mitigating a law of excessive severity: 'the harshness of the laws has been softened (legum asperitate lenita). The penalty against adulterers who attack the wives of others must no longer be the sword'. ${ }^{31}$ Frederick also reissued Norman laws only to subsequently soften them: first issuing a law of King Roger prescribing capital punishment for the kind of manslaughter where a man throws a club or rock and kills a man in doing so; but Frederick in the law immediately following makes an exception for those who kill others by accident by throwing rocks or clubs in uninhabited places, or where they did not believe anyone would be passing. ${ }^{32}$ The provision and application of the law is not particularly remarkable - the logic of introducing such an exception is easy to comprehend - but the phrasing and introduction are worth noting: 'in order to mitigate in an imperial manner (imperialiter mitigantes) the penalty established by the preceding

\footnotetext{
${ }^{29}$ Corpus Juris Civilis, Codex, 1.1.17; cf. the comments of Justinian's first and second prefaces, which make similar assertions, including the opening argument that many emperors had realised the need to correct the laws, but few had managed to accomplish it.

${ }^{30}$ Codex, 1.17.1.1.

${ }^{31}$ Constitutiones, 3.74 (Powell 1971: 145).

${ }^{32}$ Constitutiones, 3.88-9 (Powell 1971: 149-50).
} 
law .... ${ }^{33}$ Given the structure and language used, drawing attention to the change, one might assume that Frederick wished the imperial act of mitigation to be noted.

What, if any, significance do these editorial decisions and imperial asides in the Constitutions hold? How should the historian understand Frederick's decision (or that of his compilers) to note and acknowledge how his new code built on, and diverged from, the patterns of his predecessors? One might argue that it simply demonstrates Frederick's fundamental legal flexibility: he was ready to be 'Roman' or 'Norman' as required, but his laws and his code bent to necessity. Moreover, it would be possible to argue that each of these amended laws follow a particular (and pragmatic) logic: Frederick and his compilers modified their legal models and material to meet the social and political needs of the Kingdom of Sicily in 1231. Those needs had of course changed in the three decades since the end (and rather chaotic collapse) of the Norman monarchy in Sicily, the last significant law-giving period for the kingdom. Social needs and penal standards had - even more obviously - changed since the end of the western empire and Justinian's day. From a purely practical perspective, then, what is evident in these legal changes - both in changes demanding greater legal violence and those requiring more gentle treatment of offenders - is the necessary negotiation required when Roman legal reasoning met the realities of feudal society. ${ }^{34}$

I should, however, like to offer an additional (and not necessarily alternative), 'rhetorical' way of understanding the process at work here. It is necessary to appreciate what Frederick gained by drawing attention - within the body of the law code itself - to the changes he had made, the punishments he had mitigated and increased. Frederick utilised the setting down of a new code to make a rhetorical and legal point about his own authority. Rather than stipulate what the punishment will now be, he emphasises the change to past practices of lawful violence. That action positions Frederick as someone who is more than a mere imitator of his Roman predecessors or an imitator of Norman law-giving kings: it confirms his status as an emperor who negotiates on equal terms with past rulers, just as Constantine had asserted that he alone, as emperor, had the ability to interpret in matters of 'equity and law' (aequitatem iusque). ${ }^{35}$ That Frederick is seen to be weighing and determining which punishments are appropriate not only makes the code his 'own': it seals his imperial discretion to determine how law should operate. ${ }^{36}$

Imperial posturing sometimes means severity, sometimes clemency. It can mean both at once within a single text. What matters is that the level of violent punishment

\footnotetext{
${ }^{33}$ Constitutiones, 3.89 (Powell 1971: 149).

${ }^{34}$ Cf. Mayali (1994).

${ }^{35}$ Corpus Juris Civilis, Codex, 1.14.1.

${ }^{36}$ For the significance of imperial authority's ability to dispense from law in 13th-century political thought, see Pennington (1993).
} 
associated with the law is a fit matter for discussion for a legislator (and that the compilers of Frederick's code understood this). This is not blind copying from Roman Law; it is constructive remodelling. One may also detect a hint of this in the final title of the Constitutions, in which Frederick explains that law is about more than individual reputation, and the compilation of the code stands as a lasting monument: "that we may in our days destroy the injuries of the past by which the tongue of the law (iuris lingua) was silenced'. ${ }^{37}$ One might infer from that mention of 'silencing' that these discussions of how (and sometimes why) the law and its penalties have been amended are integral to the law itself; they are part of the 'tongue of the law'.

Among Frederick's modern biographers, David Abulafia, in particular, has been critical of the assumption that Frederick's Constitutions were designed as a wholehearted and fully-fledged emulation of Roman imperial law-making. Abulafia cautions that the 'Roman' quality of the text is not consistent throughout the Constitutions, and its Roman-ness does not necessarily run as deep as is sometimes assumed. Frederick (or rather his compilers) borrowed some ideas from Roman law, but was not reliant on a Roman model for its structure or purpose. ${ }^{38}$ Frederick's law is better understood as a blend of old and new; ${ }^{39}$ it should not be mischaracterised as wholly or straightforwardly Roman. An analysis of the Constitutions which focuses on what Frederick has to say about the mitigation of punishment or the necessity of judicial violence supports that view, although for different reasons. Uncomplicated imitation of Roman emperors was never the aim for Frederick: his moments of imperial self-definition were achieved by intervening to alter Roman laws, and by drawing attention to that alteration and intervention in the body of the Constitutions. Frederick was opening up a dialogue with past emperors and, perhaps paradoxically, enhancing his own imperial authority by doubting and challenging the decisions on punishment made by past emperors.

Outside the schools and the world of the glossators, the Constitutions was a body of laws, a text for consultation, reference, and use, not necessarily to be read 'through' or following the order which Frederick's compilers had ordained. One should not make the mistake of assuming that medieval users of law would have come to or 'read' the text in the same way as modern legal historians, or as I have done in this papermoving through the text, noting and listing the moments of agreement and disagreement between Frederick and classical Roman emperors. And yet, what those moments do is build up an overall impression which cannot be avoided: that of a dialogue. There are a sufficient number of references to, and discussion of, past policies of

\footnotetext{
${ }^{37}$ Constitutiones, 3.94 (Powell 1971: 151-2).

${ }^{38}$ Abulafia (1988: 203).

${ }^{39}$ Abulafia (1988: 208).
} 
imperial and royal punishment that the Constitutions of Melfi serve to make the law code the place where past and present rulers meet to discuss the justice of punishment.

\section{CANON LAW AND PENITENTIAL VIOLENCE}

This paper now turns to another form of law undergoing systematic change in the 12th century; a law which-like Frederick's Constitutions - was engaged in a discussion about the proper measure of authority, lawfulness, and violent coercion. It is perhaps more surprising to find those similarities in canon law - the law of the church. Yet, just as dialectical reasoning and royal designs combined to push towards systematisation in the secular legal systems of this period, the same process can be observed at work in the law of the church. ${ }^{40}$

While attempts to systematise and impose order on the canons (the body of authoritative opinions, gathered from such sources as the Church Fathers and church councils) were not new in the 12 th century, ${ }^{41}$ the attention paid to organising and ordering the canons dramatically increased, and the body of canon law achieved a relatively fixed form with Gratian's Decretum, c. $1140 .{ }^{42}$ More strikingly, in the canonical collections of this period, and in the texts which were developed by canonists to assist in the application of the law, a debate similar to that in civil law is being stagedabout the appropriate use of violence, and an argument about how law and punishment defined the relationship of the present to the past. There may be two objections to drawing this sort of comparison. The first is, plainly, that canon law does not deal with 'violence' in the same way as secular law. It has a different conception of offence; it is concerned with sin, rather than crime. Indeed, a basic observation amongst 12th-century canonists is that, though sin may occur in the commission of an act considered a crime by human positive law, not all that is a crime is necessarily sinfulmost obviously when the positive law which defines 'crime' is itself based on immoral premises. The point does not need to be laboured: canon law imagined and constructed its offences differently to secular law. ${ }^{43}$ Secondly, when it came to the use of violence to punish particular behaviours, those who enacted canon law did not have the same options - one reason why heretics were handed over to the temporal power for fleshly correction. However, canon law had a category of penitential punishments which

\footnotetext{
${ }^{40}$ For an overview of these changes, see Hartmann \& Pennington (2008).

${ }^{41}$ Gaastra (2006).

${ }^{42}$ For the complex textual history of the Decretum, see Winroth (2000).

${ }^{43}$ Cf. Mäkinen \& Pihlajamaki (2004).
} 
required the priest to prescribe for the sinner a form of punishment against the self as a means of making recompense for sin-most obviously through actions such as keeping vigil, fasting, or being (in extreme cases) cut off from the life of the church. In most of these forms, punishment might be prescribed by the priest, but administered by the individual. For just this reason, canon law-like civil law-was subject to a similar set of discussions about whether the punishments which prevailed in the past were to be moderated or intensified.

The techniques and guiding principles of legal interpretation necessarily differed considerably between canon and civil law. However, just as Frederick II claimed both the right and the authority to determine which old laws were to be annulled, amended, or upheld, so too did canonists assert their responsibility to consider past pronouncements and arrive at the correct interpretation of the canons. This was not an identical position or power, but they exhibit some compelling parallels. The classic description of canonist legal activity in this period is as the process of drawing 'harmony from dissonance' ${ }^{44}$ That supposedly describes a process whereby canonists would collect the canons - authoritative statements of past practice and past thinking - and work to reconcile any differences between their recommendations. In practice, this entailed understanding how one pronouncement of a Church Father might be able to fit with another; it might require harmonisation by explaining that two apparently contradictory pronouncements by church councils could be brought into agreement by appreciating that each applied to a slightly different set of circumstances. And yet, there was plainly difficulty. This was why so many early canonists, faced with authoritative pronouncements which faced in different directions, could offer no clear solution - but advised the priest to 'love and do what you will (habe caritatem et quod vis fac)' - an Augustinian maxim. ${ }^{45}$ Adhering to the 'spirit' of the law was preferable to applying the letter without consideration.

What a description of the process of creating medieval canon law as 'harmony from dissonance' may inadvertently obscure, however, is the epistemological conflict at the heart of this task. This was twofold: first of all, on the part of the compilermaking a set of decisions about inclusion/exclusion, framing, and ordering. Secondly, on the part of the priest (in the first instance; subsequently a hard problem could be referred up the hierarchy) who had to work out exactly which canon was appropriate to the situation which faced the sinner before him; and how the rules should be applied to the particular case. The reader (the confessor preparing to determine a penance) had to bring the canons into harmony with reality.

\footnotetext{
${ }^{44}$ Kuttner (1960).

${ }^{45}$ Cf. Constable (1999), Brasington (2004).
} 
One - admittedly anecdotal - illustration of the problem is found in a work by Caesarius of Heisterbach, a Cistercian monk, entitled The Dialogue on Miracles, written between 1220 and $1235 .{ }^{46}$ The Dialogue represents a set of exemplary and miraculous tales designed to explain virtue and doctrine to novice monks. Amongst the many exempla contained in the Dialogue are a series of tales about the interpretation of the canons and the setting of penance. These reflect on the ability of the individual priest to shape the penitential punishment according to both the guidance of the canons and the circumstances (and psyche) of the sinner before them. One of Caesarius' exempla describes how Pope Innocent III dealt with a contested question of punishment. Innocent was asked to judge the appropriate punishment for a woman who had borne a child by her own son; determining the appropriate punishment for the woman was a question which had defeated everyone else who had considered the case. ${ }^{47}$ Innocent assessed the woman's contrition and found it genuine, determining that the woman's previous shame and previous suffering had been sufficient—nothing further was required in recompense of the sin. But within the curia, this view was not universally supported. One of Innocent's own cardinals complained that this penance was too light for such a serious sin, doubting Innocent's ability to apply the rules to the circumstance. The tale concludes when Innocent III invites divine intervention to determine whether or not he had punished correctly: the pope asked God to possess him with a demon if his judgment was in error; or, if the penance was appropriate, to possess the cardinal. Immediately a demon possessed the cardinal, vindicating the pope's judgment.

The debate over the proper form of punishment to be imposed on the sinful woman was only settled by divine intervention, and a dramatic and shocking intervention at that. It suggests something about the ambiguities lurking here, the capacity of the law for complexity and the difficulties created by that space left for interpretation. Even the legal judgments of Innocent III were open to question if they were perceived to stray too far from appropriate severity. This problem could be acute, and though Caesarius presents it in its most dramatic form, it evidently had a reality beyond exempla collections.

The difficulty of judging appropriate penitential punishment in every case is one of the reasons that a genre of summae de poentitentia developed in the late 12th and early 13th centuries: a 'new' kind of penitential literature whereby more learned scholars synthesising their knowledge of the canons, advised local priests (some with

\footnotetext{
${ }^{46}$ Caesarius of Heisterbach, Dialogus miraculorum, edited by J. Strange (2 volumes., Cologne, J. M. Heberle and H. Lempertz, 1851).

${ }^{47}$ Caesarius, Dialogus miraculorum, 2.11 (Strange 1851: 77-8).
} 
limited Latin) on how to measure out their penances. ${ }^{48}$ In addition to introducing the reader to the principles of penitential practice, they explain the calculus by which one matches the degree of penitential punishment to the circumstances of the offence.

This is what provides the context for canon law discussions of the 'historical' nature of punitive violence, and the construction of a relationship between law and lawfulness, physical chastisement, and particular temporal regime. The summa de poenitentia opens up questions about how, exactly, violence should be applied; how old canons should be read; and the modern circumstances in which diverged from old principles is not merely justified, but warranted. The three examples of that genre I take here from come from the summae of Thomas of Chobham (1160-1233/6, subdean of Salisbury Cathedral); Robert of Flamborough (a canon of St Victor, Paris, in the early 13th century), and Alan of Lille (c.1128-1202/3, a Parisian master of theology). What is striking is that all three of these texts follow a broadly similar line of argument.

Thomas of Chobham's Summa confessorum (c.1215) faced the question of how the priest should adapt himself and his penitential punishments to the frame provided by the canons. ${ }^{49}$ The key, Thomas explained, was to appreciate that certain penitential punishments can be moderated, whereas others are immutable. He thus introduces the idea of two distinct categories of 'law' on punishment. Secondly, Thomas introduces a temporal shift. A difference of approach should be recognised - and permittedbetween penitential punishment as it was imposed in ancient times, and punishment as it is imposed today. Moderns (homo nostri temporis) cannot be expected to endure the severest kinds of fasting, vigil, and exile that might be expected as punishment in ancient times. Thomas here indicates a tripartite relationship between the interpretation of law, the measure of lawful violence, and human history. One cannot read the canons correctly_or impose punishment appropriately — if one does not bear in mind one's own historical position. Precisely the same relationship is indicated in Robert of Flamborough's Liber Poenitentialis, c.1208-13). ${ }^{50}$ Robert noted that the ancient canons advocate heavy penances, but argues that such severe punishments are no longer suitable; considering them 'excessively oppressive' (graves admodum) and severe (asperae). The task for the 13th-century priest then became the disentangling of the ancient canons and, where necessary, mitigating the punishments there advocated.

The same description of the confessor's role - part of an account which set out the same historical movement from more severe to more moderate penitential

\footnotetext{
${ }^{48}$ Payer (1984), Goering (1978).

${ }^{49}$ Thomas of Chobham, Summa Confessorum, edited by F. Broomfield (Louvain, Éditions Nauwelaerts, 1968), 7.1.1a, (1968: 325).

${ }^{50}$ Robert of Flamborough, Liber poenitentialis, edited by J. J. F. Firth (Toronto, University of Toronto Press, 1971), book 5, prologue (1971: 203).
} 
punishments - had been made in Alan of Lille's Liber Poenitentialis, a slightly earlier text than that of Thomas or Robert. ${ }^{51}$ For Alan, penitential punishments had once been considerably more severe and more rigidly imposed on offenders - but that related to the historical condition of humankind in those days: 'olim natura humana robustior'. In the present day, it was necessary to consider human infirmity; antique injunctions were to be reconsidered. More importantly, Alan provided a further explanation for this modern lightening of penances, a reasoning which is only implicit in Thomas of Chobham and Robert of Flamborough. Alan compared the process to that of an emperor promulgating laws for his people. When he first does so, Alan explained, the emperor is more cautious, because he has not established himself with regard to the population: hence he punishes transgressors of law with stricter penalties to establish right and wrong. But, as this reasoning suggests, once the law has been established and its limits understood, then punitive violence may be softened.

These discussions of 'antique' and 'modern' punishments are, of course, only one aspect of these texts on penitential practice - texts which are occupied with many questions about sin and appropriate punishment. But they should be noted for drawing that connection between legitimacy of law, punitive violence, and temporal regime. Of course, unlike Frederick II (or his Norman predecessors), who at times argue that human wickedness has increased in their own day, legitimising greater legal punishments, these canonists argue that temporal change means that punitive violence should be lessened, mitigated, the sharpness of law relaxed.

A further parallel to the legal commentary of both canonists and civil lawyers is found in the schools of theology, where scholastic masters were addressing - albeit from a different angle - a similar category of questions about the relationship between law, punitive violence, and historical change. The examination of those three categories was prompted by theologians' attempts to understand the relationship between Old and New Testaments. How, exactly, the world had been changed by the fact of the Incarnation was a major point of theological discussion for the 12th- and 13th-century schools. Part of that discussion focused on law, and the extent to which Mosaic Law (with its detailed and often severe provisions) had been abrogated by the 'new law' of Christ. The schools of theology discussed how law had changed, and whether the old law of the Old Testament still had any ongoing validity. ${ }^{52}$ In these discussions, scholastic theologians repeatedly made the point that the kind of punitive violence which can be considered appropriate and legitimate is directly connected to the kind of temporal regime one is living under.

\footnotetext{
${ }^{51}$ Alan of Lille, Liber Poenitentialis, PL.211.293B.

${ }^{52}$ This is a discussion I explore further in Justice and Mercy: Moral Theology and the Exercise of Law in Twelfth-century England (Manchester, Manchester University Press, forthcoming).
} 
The problem for theologians was twofold: it was not in dispute that Christ's new law in some way meant a diminishing of violence; the command to love one's enemies, or to turn the other cheek - whether interpreted as 'personal' or taken as setting out a new scheme of social relations - was a command that violence should be lessened. But what that meant in practice was a very large question. There was also a question of how much of the old law survived in the new - that is, whether anything of the "lex talionis' (the principle of 'an eye for an eye') might be preserved; even if the multiple dietary and behavioural precepts of Deuteronomy and Leviticus were abrogated. What, exactly, did it mean to say that Christ 'had come to fulfil [the old law], not to abolish it' (Matt. v.17)? ?3

An insight into the discussions in the schools is provided by a gloss on Deuteronomy produced c. 1187 by Stephen Langton. At that time Langton was a master of theology in Paris; he would later become Archbishop of Canterbury (1207-28). Langton's gloss wrestled with the need to define precisely the terms of this relationship between old and new laws: how they might be said to be both contrasting and complementary. ${ }^{54}$ Mosaic law, Langton suggests, might be at once a particular historical enactmentfitted to the circumstances of the Israelites of the Old Testament - but also of enduring value, with something to teach the present day, despite its differences in form and substance..$^{55}$

What both the canonists' and theologians' discussions demonstrate is that medieval writers had a sharp understanding of the interaction between history and law, and examined that history primarily through the 'violence' of law. ${ }^{56}$ It was a means of assessing both minor and major historical changes. Participating in medieval laweither as a lawgiver, or as someone imposing lawful punishment - entailed making a decision about the kind and extent of violence that could rightly be used against an offender. But that was not a decision which was based on the offence alone-it had also to be based on one's position in time and relationship to history. In that sense, 12th- and 13th-century law did something more complex than nostalgically look back on the 'good laws' of past kings and great Roman lawgivers and attempt to follow their enactments. It invited discussion; while dialogue with past lawmakers could in itself be used as a demonstration of one's own lawfulness.

\footnotetext{
${ }^{53}$ See Smalley (1974).

${ }^{54}$ For this commentary, see Lacombe et al. Studies on the Commentaries of Cardinal Stephen Langton (reprinted from Archives d'histoire doctrinale et littéraire du moyen âge, 1931), 160-6.

${ }^{55}$ Stephen Langton, Commentary on Pentateuch (Bibliothèque Nationale de France, Latin 14415, f.243v).

${ }^{56}$ This paper has deliberately avoided using the medieval term 'violentia' or chasing after its multiple meanings during this period. It has instead used 'violence' as a synthetic category to encompass punishment and physical chastisement. For some reflection on the complexity of the medieval term, see McHaffie (2018).
} 


\section{CONCLUSION: NEW REGIMES}

This paper has argued that a discussion of the violent punishments of past (now disapplied) law assisted medieval lawgivers in asserting both the 'lawfulness' of particular laws and the legitimacy of their law-giving exercise as a whole. Describing how past rulers had used violence to curb wickedness, in ways which had been legal in their own day but which were now in need of amendment, enhanced the legal authority of those who had the capacity (intellectual or political) to intervene in process of punishment.

It may be noted that some of themes discussed in this paper echo the theoretical framework articulated by Walter Benjamin in his Zur Kritik der Gewalt. ${ }^{57}$ In particular, it mirrors Benjamin's understanding of positive law as an institution which exists in order to create and define legal ends for violence; and his argument that positive law operates by declaring and sanctioning its own legality and hence the lawfulness of its own use of violence. ${ }^{58}$ For Benjamin, it was impossible to step outside positive law to assess the legitimacy of its use of violence. This, of course, is precisely what Frederick II's Constitutions purported to do: critiquing past violence as a means of demonstrating his own law-giving legitimacy. Similarly, medieval canonists did not dispute the righteousness of penitential canons in themselves, only the right circumstances of the application. This, therefore, is an explanatory model with something to recommend it when thinking historically_medievally — even given the considerable differences between medieval and modern 'states' and the capacity of state authority to enforce violent, lawful ends.

What is also evident is that the discussions described here-both in secular and canon law - about the legitimacy of law, tied to the degree of its violent punishment for offenders, are similar to those which take place in modern polities. Those discussions encompass questions about whether law punishes offenders in the 'right' way, and whether penology is moving in the 'right' direction, towards a better ordered society; about how perceived changes in criminal behaviour should be mirrored in changes in legislative and sentencing responses. As many sociologists and criminologists have pointed out - these responses are as much conditioned by the demands of political rhetoric as they are the considered needs of society. ${ }^{59}$

Medieval law was complex in ways that are not always immediately recognisable. ${ }^{60}$ It should not be doubted that ideological assertion was an important — even central-

\footnotetext{
${ }^{57} \mathrm{I}$ am grateful to the participants at the joint UK-US workshop on violence, and the organisers of this volume, for their suggestions on this point.

${ }^{58}$ Benjamin (1986: 280).

${ }^{59}$ For instance, see Bottoms (1995). For a counter-view, see Matthews (2005).

${ }^{60}$ For a reminder of the need to rethink assumptions about what medieval law 'was' and what it was 'for', see Colman (1974).
} 
element in their creation and enactment. But the relationship with the past was conceived as a dialogue (even an argument). It was not merely a by-the-numbers reissuing of authoritative platitudes on law and violence. Exploring what those laws say about the violence of the past invites us to consider a nexus of ideas about legitimacy, lawfulness, the relation of whole to part, and the relation between past and present. In these medieval examples, claims about knowledge of the law-knowing how violence should be applied in punishing offenders - are tied up with claims about power over the law - the authority to make and unmake previous historical enactments. In that sense, a discussion within law codes about what past lawgivers had got right or wrong on punishment might establish a sense of 'modernity' in a medieval polity. It denoted a break with the past, and the rhetorical promise of a new regime-a regime more just because it was temporally distinct; and a regime more lawful because it outdid the laws of the past.

\section{REFERENCES}

Abulafia, D. (1988), Frederick II: A Medieval Emperor (London, Allen Lane).

Benjamin, Walter (1986), 'A Critique of Violence', in Reflections: Essays, Aphorisms, Autobiographical Writings, trans. E. Jephcott (New York, Schocken Books), 277-300.

Berman, Harold J. (1983), Law and Revolution: The Formation of the Western Legal Tradition (Cambridge, MA, Harvard University Press).

Bottoms, A. (1995), 'The Philosophy and Politics of Punishment and Sentencing', in C. Clarkson \& R. Morgan (eds) The Politics of Sentencing Reform (Oxford, Clarendon Press), 17-49.

Brasington, B. (2004), Ways of Mercy. The Prologue of Ivo of Chartres (Münster, Lit Verlag).

Broomfield, F. (1968), Thomas of Chobham, Summa Confessorum (Louvain, Éditions Nauwelaerts).

Byrne, Philippa (2019), Justice and Mercy: Moral Theology and the Exercise of Law in Twelfth-century England (Manchester, Manchester University Press).

Colman, Rebecca V. (1974), 'Reason and Unreason in Early Medieval Law', Journal of Interdisciplinary History, 4(4): 571-91. https://doi.org/10.2307/202713

Constable, G. (1999), 'Love and Do What You Will': The Medieval History of an Augustinian Precept (Kalamazoo, MI, Medieval Institute Publications).

Diehl, P. D. (1996), 'Overcoming Reluctance to Prosecute Heresy in Thirteenth-century Italy', in Scott L. Waugh \& P. D. Diehl (eds) Christendom and Its Discontents: Exclusion, Persecution, and Rebellion, 1000-1500 (Cambridge, Cambridge University Press), 47-66.

Dilcher, H. (ed.) (1973), Constitutiones Regni Siciliae (Glashütten, D. Auvermann).

Downer, L. J. (ed.) (1972), Leges Henrici Primi (Oxford, Clarendon Press).

Firth, J. J. (ed.) (1971), Robert of Flamborough, Liber poenitentialis (Toronto, University of Toronto Press).

Gaastra, A. H. (2006), 'Penance and the Law: The Penitential Canons of the Collection in Nine Books', Early Medieval Europe, 14(1): 85-102. https://doi.org/10.1111/j.1468-0254.2006.00175.x

Goering, J. (1978), 'The Summa of Master Serlo and Thirteenth-century Penitential Literature', Mediaeval Studies, 40: 290-311. https://doi.org/10.1484/J.MS.2.306229 
Hartmann, W. \& Pennington, K. (eds) (2008), The History of Medieval Canon Law in the Classical Period, 1140-1234: From Gratian to the Decretals of Pope Gregory IX (Washington, DC, Catholic University of America Press).

Herde, P. (1994), 'Literary Activities of the Imperial and Papal Chanceries during the Struggle between Frederick II and the Papacy', in William Tronzo (ed.), Intellectual Life at the Court of Frederick II Hohenstaufen (Washington, DC, National Gallery of Art), 227-39.

Jahner, J. (2014), 'The Mirror of Justices and the Art of Archival Invention', Viator, 45(1): 221-46. https://doi.org/10.1484/J.VIATOR.1.103789

Jamison, E. (1929), 'The Administration of the County of Molise in the Twelfth and Thirteenth Centuries', English Historical Review, 44(176): 529-59.

https://doi.org/10.1093/ehr/XLIV.CLXXVI.529

Karn, N. (2010), 'Rethinking the Leges Henrici Primi', in S. Jurasinski, L. Oliver \& A. Rabin (eds) English Law Before Magna Carta (Leiden, Brill), 197-220.

https://doi.org/10.1163/ej.9789004187566.i-330.42

Kruger, P. \& Mommsen, T. (eds) (1893-95), Corpus Juris Civilis, 3 volumes (Berolini, Apud Weidmannos).

Kuttner, Stephan (1960), Harmony from Dissonance: An Interpretation of Medieval Canon Law (Latrobe, PA, Archabbey Press).

Lacombe, Georges, Smalley, Beryl \& Gregory, Alys L. Studies on the Commentaries of Cardinal Stephen Langton; reprint from Archives d'histoire doctrinale et littéraire du moyen âge (1931).

Lambert, T. B. (2017), Law and Order in Anglo-Saxon England (Oxford, Oxford University Press). https://doi.org/10.1163/ej.9789004187566.i-330.42

Mäkinen, V. \& Pihlajamaki, Heikki (2004), 'The Individualization of Crime in Medieval Canon Law', Journal of the History of Ideas, 65(4): 525-42. https://doi.org/10.1353/jhi.2005.0016

Matthews, R. (2005), 'The Myth of Punitiveness', Theoretical Criminology, 9: 175-201. https://doi.org/10.1177/1362480605051639

Mayali, Laurent (1994), 'Foreword: Social Practices, Legal Narrative, and the Development of the Legal Tradition', Chicago-Kent Law Review, 70: 1469-77.

McGinn, B. (1978), 'Angel Pope and Papal Antichrist', Church History, 47(2): 155-73. https://doi.org/10.2307/3164731

McHaffie, M. W. (2018), 'Law and Violence in Eleventh-century France', Past \& Present, 238(1): 3-41. https://doi.org/10.1093/pastj/gtx056

Meredith, J. (1994), 'The Arch at Capua: The Strategic Use of Spolia and References to the Antique', Studies in the History of Art, 44: 109-26.

Murphy, Andrew R. (2009), 'Longing, Nostalgia and Golden Age Politics: The American Jeremiad and the Power of the Past', Perspectives on Politics, 7(1): 125-41.

https://doi.org/10.1017/S1537592709090148

Oldfield, Paul (2009), 'The Kingdom of Sicily and the Early University Movement', Viator, 40(2): 13550. https://doi.org/10.1484/J.VIATOR.1.100425

Payer, P. J. (1984), 'The Humanism of the Penitentials and the Continuity of the Penitential Tradition', Mediaeval Studies, 46: 340-54. https://doi.org/10.1484/J.MS.2.306319

Pennington, Kenneth (1989), 'Gregory IX, Emperor Frederick II, and the Constitutions of Melfi', in S. Chodorow \& J. Sweeney (eds) Popes, Teachers, and Canon Law in the Middle Ages (Ithaca, NY, Cornell University Press), 53-61.

Pennington, Kenneth (1993), The Prince and the Law: Sovereignty and Rights in the Western Legal Tradition (Berkeley, CA, University of California Press).

Powell, James (trans.) (1971), The Liber Augustalis or Constitutions of Melfi (Syracuse, NY, Syracuse University Press).

Sabapathy, J. (2014), Officers and Accountability in Medieval England, 1170-1300 (Oxford, Oxford University Press). https://doi.org/10.1093/acprof:oso/9780199645909.001.0001 
Seipp, David J. (1999), 'The Mirror of Justices', in Jonathan A. Bush \& Alain Wijffels (eds) Learning the Law: Teaching and the Transmission of English Law, 1150-1900 (London, Hambledon Press), $85-112$.

Smalley, Beryl (1974), 'William of Auvergne, John of La Rochelle and St. Thomas Aquinas on the Old Law', in St. Thomas Aquinas 1274-1974: Commemorative Studies, Vol. 2 (Toronto, Pontifical Institute of Mediaeval Studies), 11-74.

Spiegel, G. (2016), 'Structures of Time in Medieval Historiography', The Medieval History Journal, 19(1): 21-33. https://doi.org/10.1177/0971945816638616

Strange, J. (ed.) (1851), Caesarius of Heisterbach, Dialogus miraculorum, 2 volumes (Cologne, J. M. Heberle and H. Lempertz).

Van Caengem, R. C. (1991), 'Criminal Law in England and Flanders under King Henry II and Count Philip of Alsace', in Legal History: A European Perspective (London, Hambledon Press), 37-60.

Whittaker, W. J. (ed.) (1896), Andrew Horne The Mirror of Justices (London, B. Quaritch).

Winroth, Anders (2000), The Making of Gratian's Decretum (Cambridge, Cambridge University Press). https://doi.org/10.1017/CBO9780511496639

Wormald, Patrick (1999), Legal Culture in the Early Medieval West: Law as Text, Image and Experience (London, Hambledon Press).

To cite the article: Philippa Byrne (2020), 'Medieval violence, the making of law and the historical present', Journal of the British Academy, 8(s3): 133-154.

DOI https://doi.org/10.5871/jba/008s3.133

Journal of the British Academy (ISSN 2052-7217) is published by

The British Academy, 10-11 Carlton House Terrace, London, SW1Y 5AH

www.thebritishacademy.ac.uk 